\title{
Review of Pay Satisfaction Research
}

\author{
Wang Jingjing \\ School of Nanjing University of Science and Technology, Nanjing 210000, China \\ 18262610063@163.com
}

Keywords: Pay satisfaction, Performance, Review.

\begin{abstract}
Employee pay satisfaction is an important factor affecting employee's personal performance and corporate goals. Its main influencing factors are real wage and wage growth level, social comparison, salary system characteristics and their perception, job characteristics and job input factors. Pay satisfaction has an impact on individual work attitudes, work behaviors, and job performance. It is related to organizational fairness, personality relationship, and organizational level pay satisfaction. Therefore, the study of pay satisfaction has received extensive attention. This paper reviews the existing research literature from the aspects of the effect and influencing factors of pay satisfaction, and puts forward the prospect of future research.
\end{abstract}

\section{Introduction}

The understanding of pay satisfaction has mainly experienced the following two changes. First, early scholars' research focused on a single dimension of pay level satisfaction, including pay levels, payroll and compensation systems (Miceli, etc.) to understand pay satisfaction. However, with the in-depth study of pay satisfaction, Heneman et al. proposed a multi-dimensional structure of pay satisfaction recognized by researchers. They think that pay satisfaction is not a single level of satisfaction, but employees' salary level, welfare, and Emotional responses to satisfaction in terms of salary, compensation structure, and management ${ }^{[1]}$. This emotional response includes positive or negative attitudes. From this we derive the overall concept of pay satisfaction, Miceli: "Remuneration satisfaction is the positive or negative emotional level of an individual's salary (covering multiple aspects of external and internal compensation).”

\section{Research Overview}

According to the research content and time, it can be divided into three stages. The first phase focused on the study of influencing factors (before 1971). At this time, there are some models of factors affecting pay satisfaction. Lawler concludes that pay discrepancy is the main factor, and the salary difference contains many individual factors. The second phase focuses on structural studies (1971-1990). During this period, many studies have explored the structure of pay satisfaction, and Heneman et al.'s four-factor structure of pay satisfaction is the dominant position in this period. The third phase focuses on the study of the effects (1991-present). Heneman et al believe that pay satisfaction has an impact on employees' perceptions and behaviors such as lateness, separation, turnover intention, early leave, deception, and job performance. 


\section{Influencing Factors}

\subsection{Influential Factors at the Individual Level}

\subsubsection{Individual work inputs}

Work input factors include individual factors and work related factors. Individual factors include age, marital status, gender, etc., which determine the employee's expectation of salary, which affects pay satisfaction. Specifically, older or married employees have lower levels of pay satisfaction because they believe they are more likely to work in their work experience or social needs than their younger or unmarried employees. "In terms of gender, men are less satisfied than women, although men's wages are higher than women's.” Maior's “female employee paradox”. Work-related input factors include employee qualifications, work experience, job title, length of service, etc. The higher the level of employee-related input, the higher the employee's expectation of salary, and the higher the employee's salary expectation, the lower the pay satisfaction. However, studies have shown that individual factors (including age, gender, marriage, and race) of employees are not directly related to pay satisfaction.

\subsubsection{Individual salary comparisons}

Employee compensation comparisons can be divided into internal comparisons, external comparisons, and individual comparisons. Studies by Williams et $\mathrm{al}^{[2]}$. show that employees' internal comparisons with external comparisons have a greater impact on pay satisfaction. When the individual's salary is higher than the social standard, the higher the employee's pay satisfaction level, the internal comparison, when the employee thinks that his salary is higher than the salary of the same position as his colleagues, it will increase his pay satisfaction. Salary comparison is positively correlated with welfare satisfaction, and positively correlated with salary level and salary management ${ }^{[3]}$ (Judge, 1993; Williams, 1995). Other studies have shown that employee compensation will vary with organizational environment and cost of living. At the same time, the fair sensitivity of employees will also affect the salary comparison of employees.

\subsubsection{Employee real wages and salary increases}

Henman (1985) suggests that there is a significant correlation between real wages and pay satisfaction; subsequent scholars such as Williams and Nguyen argue that there is only a weak correlation between real wages and pay satisfaction; In the special population, the relationship between wage level and wage satisfaction is negatively correlated. Therefore, the actual level of employees' effects on pay satisfaction is not stable. The correlation between salary increase and pay satisfaction cannot be justified in Lawler's salary level satisfaction model, but the salary increase affects the perception of salary, and we expect the salary increase ratio to be positively related to pay satisfaction (Williams, 2006).

\subsection{Organizational Factors}

\subsubsection{Organizational Compensation Management}

Before Heneman proposed the "four dimensions" of compensation, few researchers studied the relationship between compensation management and pay satisfaction. Subsequent studies have found that compensation management characteristics and perceptions are related to pay satisfaction. This is mainly reflected in the two aspects of compensation management and its reform. In terms of 
compensation management, the study found that the level of employee perception has an impact on the relationship between compensation management and pay satisfaction. Specific performance, perceived performance wage plan, compensation system, actual salary level and salary increase time are all related to pay satisfaction (Judge, 1993); employees with high performance level are lower than employees with lower performance level; welfare management and Welfare satisfaction is positively correlated (Cappelli et al., 1990; Wiliams, 1995). In terms of compensation reform, salary performance satisfaction after the introduction of the flexible performance plan was significantly higher than before the introduction of the plan (Schwab et al., 1988). Performance pay perceptions will also affect other aspects of payroll satisfaction, including pay levels, benefits, and management (Heneman and Schwab et al., 1988); payroll communication and payroll satisfaction (satisfying pay levels, benefits, wages, and compensation management) are straightforward And indirect relationship. Most studies on pay communication classify it as a small part of the relevant research and do not conduct a single detailed study. Existing research shows that increased pay communication can lead to more accurate feedback, better decision making, higher job commitment, increased empowerment awareness, and a deeper understanding of how to maximize organizational effectiveness. Many studies have found that employees' perceptions of pay systems or wages can improve pay satisfaction (Heneman and Judge, 2000). However, how to enhance communication can lead to positive attitudes that have not been found in past studies.

\subsubsection{Job Characteristics}

Core job characteristics include skill diversity, task integrity, mission importance, autonomy, and feedback. These five factors are considered to be important aspects of pay satisfaction. These factors help to meet other personal needs that are not met by compensation, such as autonomy. Kinicki's 2002 study found that "these factors are positively correlated with moderate pay satisfaction" ${ }^{4]}$. Among them, autonomy and information feedback have the strongest influence on pay satisfaction. Because the task with high freedom will meet the growth needs of employees, and task feedback can improve the realistic expectation of employees' salary expectations, so they are more willing to accept reality and improve pay satisfaction

\section{Future Research Direction}

\subsection{Organizational Fairness and Pay Satisfaction}

Organizational fairness is the core issue of pay satisfaction, but there is not much empirical research in the literature, so the causal relationship is not clear. The study found that the explanatory variance of the distribution fairness to pay satisfaction (187\%) is more than twice the procedural fair interpretation variation (86\%) (Folger et al., 1989); the distribution equity is more relevant to the pay satisfaction than the procedural fairness. 1 . In terms of interaction, procedural fairness is the adjustment variable that assigns fair influence on theft behavior (Green berg, 1990,); distribution fairness affects organizational commitment through pay satisfaction, but procedural fairness has no direct impact on pay satisfaction, it is satisfied by superiors. Degree affects organizational commitment (DeConinck et al); organizational justice is an important factor in pay satisfaction (Wu Xiao tong et al., 2006) ${ }^{[5]}$. However, the literature shows that organizational fairness also includes fairness in interaction, and its relationship with pay satisfaction has not been studied much. Therefore, the complex relationship between organizational justice and pay satisfaction needs further study. 


\subsection{The Effect of Individual Personality on Pay Satisfaction}

The time to study the impact of individual personality on salary satisfaction has matured (Shaw et al., 1999). Shaw and other studies have shown that positive emotions are significantly correlated with salary satisfaction, while negative emotions are not significantly related to salary satisfaction; Zhao Yong et al. The same is true. The results of Cable et al. (1994) show that: high materialists prefer high pay levels, internal controllers prefer flexible welfare programs, individuals with high individualism and high self-efficacy prefer individuals rather than team pay, and high-risk avoiders Like a fixed or not contingent salary system, high self-efficacy prefers skill compensation rather than position compensation ${ }^{[6]}$. It can be seen from the above that the relationship between personality and salary satisfaction is complex, and further research is needed. Moreover, personality may play a mediating role between individual basic variables, job characteristics and salary satisfaction, but it has not been proved by empirical research.

\section{References}

[1] Heneman H.G. 1985. Pay Satisfaction: Its Multidimensional Nature and Measurement. International Journal of Psychology. V20:129-141.

[2] Zeffane. 1994. Understanding Employee Turnover: The Need for a Contingency Approach. International of Manpower. V15:22-38.

[3] Price J. L. 2007. The Study of Turnover. Ames: Iowa State University Press, 35.

[4] Williams M. L, McDaniel M. A, Nguyen N. T. A. 2006. A Meta-Analysis of The Antecedents and Consequences of Pay Level Satisfaction. Journal of Applied Psychology, V2. 392-413.

[5] Quarles. 1994. An Empirical Examination of a Model of The Turnover Intentions of Information Systems Auditors. Journal of Applied Business Research. V10. 44-60.

[6] Lambert, Hogan, Barton. 2001. The Impact of Job Satisfaction on Turnover Intent: A Test of a Structural Measurement Model Using a National Sample. Social Science Journal, V2:233-251. 